\title{
Interactive comment on "Mātauranga Māori in geomorphology: existing frameworks, case studies and recommendations for Earth scientists" by Clare Wilkinson et al.
}

Clare Wilkinson et al.

clare.wilkinson@pg.canterbury.ac.nz

Received and published: 23 May 2020

Dear Professor Viles and our two referees,

We extend great thanks to the two reviewers for their constructive feedback on our manuscript, Matauranga Maori in geomorphology: existing frameworks, case studies and recommendations for Earth Scientists (esurf-2020-5). We found many of the reviewer suggestions highly valuable, and made changes accordingly.

Please find a detailed response to both reviewers in the attached supplement. We will also provide two versions of our updated manuscript as .pdf files: one showing tracked 
changes and one without, to aid in identifying line numbers indicated in our detailed response to reviewers.

ESurfD

Again, we extend our thanks for the comprehensive reviews of our manuscript.

Sincerely, Clare Wilkinson, on behalf of the authorship team

Please also note the supplement to this comment:

https://www.earth-surf-dynam-discuss.net/esurf-2020-5/esurf-2020-5-AC1-

supplement.pdf

Interactive comment on Earth Surf. Dynam. Discuss., https://doi.org/10.5194/esurf-2020-5, 2020. 